\title{
Effect of pH Shock on the Treatment of High Concentration Organic Wastewater via a Fe/GO- Anaerobic System
}

\author{
Yecheng Lin, ${ }^{\mathrm{a}}$ Xiangzhi Wang, ${ }^{\mathrm{a}}$ Longyu Wang, ${ }^{\mathrm{a}}$ Da Yang, ${ }^{\mathrm{a}}$ and Huixia Lan ${ }^{\mathrm{a}, \mathrm{b}}$ \\ The $\mathrm{pH}$ is one of the key factors affecting microbial activity in anaerobic \\ systems. In this paper, the $\mathrm{pH}$ impact tolerance of $\mathrm{Fe}^{\circ} / \mathrm{GO}$ (zero-valent \\ iron/graphene oxide) mediated anaerobic treatment system for high \\ concentration organic wastewater was studied. The effects of a $\mathrm{Fe} / \mathrm{GO}$ \\ mediated anaerobic system on wastewater treatment, degradation \\ kinetics, and the physicochemical properties of sludge were studied at pHs \\ of 5.5 and 8.5; the separate addition of $\mathrm{Fe}^{0}$ and $\mathrm{GO}$ and a blank system \\ were used as the blank control. The results showed that the $\mathrm{pH}$ had \\ adverse effects on the treatment of each system and the physicochemical \\ characteristics of sludge. However, the $\mathrm{Fe}^{\circ} / \mathrm{GO}$ system under $\mathrm{pH}$ shock \\ maintained a relatively high $\mathrm{COD}$ cr removal rate and gas production; the \\ effluent volatile fatty acid content was the lowest, the effluent $\mathrm{pH}$ value \\ deviation from the normal range was small, the degradation rate constant, \\ and sludge concentration and flocculation performance of the mixed liquid \\ were better than those of other systems. The recovery phase of $\mathrm{Fe}^{0} / \mathrm{GO}$ \\ returned to normal in a relatively short time. These results showed that \\ adding $\mathrm{Fe} / \mathrm{GO}$ to the anaerobic treatment of high concentration organic \\ wastewater system can drastically improve the $\mathrm{pH}$ shock resistance of the \\ system.
}

DOI: 10.15376/biores.17.1. 1591-1605

Keywords: Anaerobic; $\mathrm{Fe}^{0} / \mathrm{GO}$; $\mathrm{pH}$ shock; Impact resistance

Contact information: a: College of Environment and Safety Engineering of Qingdao University of Science and Technology, Qingdao 266042 China; b: Guangdong Provincial Key Lab of Green Chemical Product Technology, Guangzhou 510640, China;

*Corresponding author: lanhuixia@163.com

\section{INTRODUCTION}

Anaerobic biotechnology has the following characteristics: a low energy demand, large potential for renewable energy via biogas production, low amount of surplus sludge, and low operating costs, so it is widely used in various high concentration organic wastewater treatments (Appels et al. 2008; Chan et al. 2009; Poh and Chong 2009). Under anaerobic conditions, the organic matter in wastewater is transformed into biogas to purify wastewater under the co-metabolism of bacteria. However, microorganisms under anaerobic conditions have strict requirements in terms of environmental conditions (especially methanogens). When the external environment fluctuates, the microbial activity will be inhibited, and the wastewater treatment efficiency will be considerably lowered. Therefore, it has become a hot research topic to improve microbial activity to resist adverse effects when environmental conditions fluctuate. It was found that the combined addition of iron series and carbon series enhanced the anaerobic fermentation system and achieved 
good research results (Zhang et al. 2020).

The $\mathrm{pH}$ is a key factor affecting anaerobic biological treatment technology. The optimal $\mathrm{pH}$ range of different microorganisms is different, and the sensitivity of different microorganisms to $\mathrm{pH}$ is different. In the process of wastewater treatment by anaerobic fermentation system, the $\mathrm{pH}$ value is constantly changing, and the fluctuation range of system $\mathrm{pH}$ value is related to wastewater quality. The cost of wastewater treatment is related to the frequency of $\mathrm{pH}$ regulation. The adverse effects of improper $\mathrm{pH}$ on the growth and reproduction of microorganisms are predominantly manifested in the following aspects: first, the decrease of $\mathrm{pH}$ will induce positive and negative charges on the surface of microorganisms, and then it will alter the absorption of nutrients by microorganisms; secondly, too high or too low $\mathrm{pH}$ value will induce ionization of organic compounds, which indirectly affects microorganisms; last but not least, an unsuitable $\mathrm{pH}$ reduces enzyme activity, which in turn affects biochemical processes within microbial cells. Therefore, it is of great research value to reduce the influence of system $\mathrm{pH}$ fluctuation on anaerobic fermentation bacterial community and to ensure the stable operation of anaerobic fermentation system, which can reduce the cost of anaerobic fermentation system to treat wastewater. Braguglia et al. (2017) found that the fermentation bacteria could remain active in a pH range of 4 to 8.5 , while the optimal $\mathrm{pH}$ for methanogens was 6.5 to $7.2 \mathrm{Lu}$ et al. (2020) found that the concentration, composition, intermediate products, and metabolic state of volatile fatty acids (VFAs) produced via the anaerobic digestion of potato peel waste were different under different $\mathrm{pH}$ conditions. In addition, the activities of acetate kinase and butyrate kinase were slightly inhibited at a $\mathrm{pH}$ of 5.0 and a $\mathrm{pH}$ of 11.0, which resulted in relatively low production of VFAs. It was found that adding ferrous materials and carbonaceous materials can stimulate the growth and reproduction of microorganisms, enhance the activity of related enzymes, and maintain high microbial activity even when the $\mathrm{pH}$ is beyond the appropriate range (Liu et al. 2012; Teng et al. 2017). This alleviates the adverse effects caused by $\mathrm{pH}$ fluctuation and provides the system with a certain amount of $\mathrm{pH}$ shock tolerance.

A cheap and green reducing agent, zero-valent iron $\left(\mathrm{Fe}^{0}\right)$ is converted into $\mathrm{Fe}^{2+}$ in an anaerobic system, which does the following: supply pollutant electrons, accelerate the degradation of organic substances, reduce the oxidation reduction potential (ORP), promote electron transfer between species, and create more favorable conditions for anaerobic digestion (Liu et al. 2012). In the development of microbial fuel cell sensors, Jia et al. (2017) used $\mathrm{Fe}^{0}$ to promote acetic acid conversion and inter-species electron transfer to delay excessive acidification and reduce the impact of excessive acidification on sensor performance, thus making the system more resistant to $\mathrm{pH}$ shocks. At the same time, $\mathrm{Fe}^{0}$ is also one of the essential micronutrient elements of methanogens and an indispensable component of the prosthetic group of methanogens. $\mathrm{Fe}^{0}$ can increase the enzyme activity of anaerobic microorganisms, reduce the inhibitory effect of $\mathrm{pH}$ shock on an enzyme, and considerably increase the methane production in the anaerobic system (Wu et al. 2015). Kong et al. (2016) put forward the idea of adding $\mathrm{Fe}^{0}$ to an anaerobic digestion system to inhibit the over acidification of food waste. During the experiment, it was found that the $\mathrm{pH}$ of the reactor without $\mathrm{Fe}^{0}$ ranged between 5.2 and 5.4, while the $\mathrm{pH}$ of the reactor with $\mathrm{Fe}^{0}$ was maintained between 7.5 and 8.0. These results showed that $\mathrm{Fe}^{0}$ can effectively inhibit the excessive acidification of the anaerobic digestion process and enhance the ability of the system to resist $\mathrm{pH}$ shock. However, $\mathrm{Fe}^{0}$ can easily accumulate at the bottom of the reactor and therefore is not fully effective. As such, fixing $\mathrm{Fe}^{0}$ to the supporting medium can prevent it from gathering together and losing its effectiveness (Stefaniuk et al. 
2016). Carbon materials with large specific surface areas, e.g., activated carbon, carbon nanotubes, mesoporous carbon, and graphene, have been proposed as carriers (Teng et al. 2017). Graphene oxide (GO), as a two-dimensional monolayer with abundant functional groups (epoxy, hydroxyl, and carboxyl), is a very promising carrier (Perreault et al. 2015). Many oxygen-containing functional groups, e.g., $\cdot \mathrm{OH},-\mathrm{O}-, \mathrm{C}=\mathrm{O}$, and more abundant hydrophilic groups, are introduced on its surface. These hydrophilic groups provide a large number of active sites for the connection of various organic molecules, macromolecules, and biomolecules, improving the possibility of GO surface functionalization and contributing to its dispersion in various solutions (Konios et al. 2014; Smith et al. 2019). At the same time, due to its large specific surface area, layered structure, and good conductivity, GO can effectively adsorb pollutants and promote interspecific electron transfer (DIET) as well as effectively reduce the impact of $\mathrm{pH}$ fluctuation on an anaerobic system and improve the methane production in an anaerobic system (Fan et al. 2018). Consequently, it is hypothesized here that the addition of $\mathrm{Fe}^{0}$ and $\mathrm{GO}$ in the wastewater treatment process can upgrade the enzyme activity of anaerobic microorganisms and strengthen the $\mathrm{pH}$ tolerance of the key enzymes of anaerobic fermentation, that is, sustain a high activity in the non-optimal $\mathrm{pH}$ range (6.7 to 7.5). It is expected that $\mathrm{Fe}^{0}$, particularly the complex combined with GO, can give full play to their respective advantages in the anaerobic fermentation system, make up for each other, enhance the $\mathrm{pH}$ shock tolerance of the system, and make the system more secure and more effective in eliminating pollutants.

This paper studied the effect of a $\mathrm{Fe}^{0} / \mathrm{GO}$ anaerobic system on treating highconcentration organic wastewater under $\mathrm{pH}$ shock conditions in order to explore the growth and reproduction of microorganisms under different $\mathrm{pH}$ conditions. In addition, this study explored the impact resistance of an $\mathrm{Fe}^{0} / \mathrm{GO}$ anaerobic system under $\mathrm{pH}$ fluctuations and provided a basis for the practical application of the new anaerobic system.

\section{EXPERIMENTAL}

\section{Wastewater and Inoculated Sludge}

Simulated citric acid wastewater was used in the experiments. The chemical oxygen demand based on $\mathrm{K}_{2} \mathrm{Cr}_{2} \mathrm{O}_{7}$ testing $\left(\mathrm{CODCr}_{\mathrm{C}}\right.$ ) was approximately $8000 \mathrm{mg} / \mathrm{L}$, and the $\mathrm{pH}$ was 4.0 to 5.0. Ammonium sulfate $\left(\left(\mathrm{NH}_{4}\right)_{2} \mathrm{SO}_{4}\right)$ and potassium dihydrogen phosphate $\left(\mathrm{KH}_{2} \mathrm{PO}_{4}\right)$ were added as the nitrogen and phosphorus sources with a CODCr:N:P weight ratio of 200 to 5 to 1 . The inoculated sludge was obtained from an upflow anaerobic sludge bed (UASB) reactor from a brewery in Qingdao, China.

\section{Experiment Methods}

Preparation of the $\mathrm{Fe}^{0} / \mathrm{GO}$

Graphene oxide was prepared according to a modified Hummer's method (Chen et al. 2013). $\mathrm{Fe}^{0}$ and $\mathrm{GO}$ at a mass ratio of 5 to 1 ( $1.0 \mathrm{~g}$ of $\mathrm{Fe}^{0}$ and $0.2 \mathrm{~g}$ of $\left.\mathrm{GO}\right)$ were placed in a $100 \mathrm{~mL}$ beaker, $20 \mathrm{~mL}$ of deionized water was added, and ultrasonic treatment was conducted for $20 \mathrm{~min}$ under nitrogen protection. Then, after ultrasound treatment, the material was put into a vacuum drying oven and dried at a temperature of $105^{\circ} \mathrm{C}$ to get the $\mathrm{Fe}^{0} / \mathrm{GO}$ composite. The amount of composite combined with deionized water was $0.06 \mathrm{~g}$. The activity of the prepared $\mathrm{Fe}^{0} / \mathrm{GO}$ composite was stable for at least 6 months, and at the end of use, the $\mathrm{Fe}^{0} / \mathrm{GO}$ composite were easily recovered with a magnet. A scanning electron microscopy (SEM) image of the prepared $\mathrm{Fe}^{0} / \mathrm{GO}$ material is shown in Fig. 1. The 
GO sheets were coated with a large number of small particles. The particles were evenly dispersed, and agglomeration was not obvious, which indicated that $\mathrm{GO}$ and $\mathrm{Fe}^{0}$ were fully and evenly compounded. The average particle size of the iron powder used was $37.4 \mu \mathrm{m}$. The BET surface areas of the $\mathrm{Fe}^{0}$, GO, and the $\mathrm{Fe}^{0} / \mathrm{GO}$ composite are shown in Table 1 . Compared with $\mathrm{Fe}^{0}$ and $\mathrm{GO}$, the BET surface area of the $\mathrm{Fe}^{0} / \mathrm{GO}$ composite was greatly increased, which was conducive to the adsorption of organic matter in the system and provided growth sites for microorganisms. This promoted the growth and reproduction of microorganisms and improved the microorganism activity, thus enhancing the wastewater treatment effects.

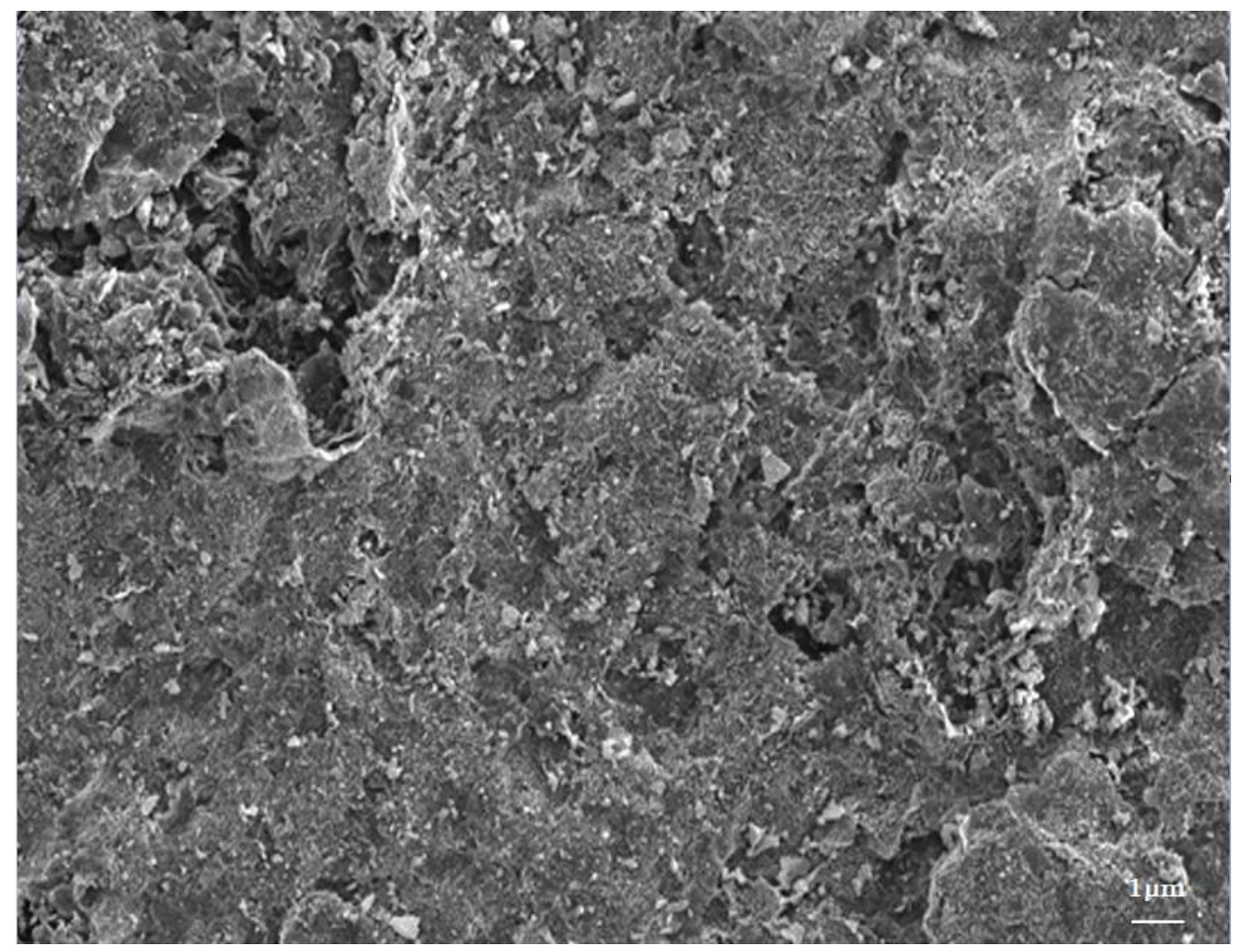

Fig. 1. SEM image of the $\mathrm{Fe} / \mathrm{GO}$ composite

Table 1. The BET Surface Areas

\begin{tabular}{|c|c|}
\hline Materials & BET Surface Areas $\left(\mathrm{m}^{2} / \mathrm{g}\right)$ \\
\hline $\mathrm{Fe}^{0}$ & 1.85 \\
\hline $\mathrm{GO}$ & 4.89 \\
\hline $\mathrm{Fe}^{0} / \mathrm{GO}$ composite & 16.72 \\
\hline
\end{tabular}

Four $500 \mathrm{~mL}$ anaerobic reactors were taken, and $200 \mathrm{~mL}$ of acclimated anaerobic activated sludge was added into each reactor. The four reactors were labeled as follows: the blank group; $\mathrm{GO}$ group; $\mathrm{Fe}^{0}$ group; and $\mathrm{Fe}^{0} / \mathrm{GO}$ group. Then, $0.2 \mathrm{~g} / \mathrm{L}$ of $\mathrm{GO}, 0.1 \mathrm{~g} / \mathrm{L}$ of $\mathrm{Fe}^{0}$, and $0.12 \mathrm{~g} / \mathrm{L}$ of the $\mathrm{Fe}^{0} / \mathrm{GO}$ composite were added into the $\mathrm{GO}$ group, $\mathrm{Fe}^{0}$ group, and $\mathrm{Fe}^{0} / \mathrm{GO}$ group, respectively, in addition to the $200 \mathrm{~mL}$ of experimental influent.

Four anaerobic reactors were placed in a constant temperature oscillator at a temperature of $37^{\circ} \mathrm{C}$. The optimal $\mathrm{pH}$ value for the growth and metabolism of anaerobic fermentation bacteria is between 6.7 and 7.5 (Zhang et al. 2020). In actual production operation, the $\mathrm{pH}$ value of the anaerobic system will not be lower than 5.5, and some bacteria will lose their removal capability when it is higher than 8.5. Therefore, the low 
$\mathrm{pH}$ value and high $\mathrm{pH}$ value were set at 5.5 and 8.5 in the $\mathrm{pH}$ shock experiment. The $\mathrm{pH}$ value of the four reactors was set at 5.5, the treatment period was $12 \mathrm{~h}$, and the effluent $\mathrm{pH}$, gas production and $\mathrm{COD}_{\mathrm{Cr}}$ removal rate of the four reactors were measured in each cycle. At the end of the seventh cycle, PN and PS, VFAs, MLSS were determined. Then the shaking table $\mathrm{pH}$ value was restored to 7.2 , and the above steps were repeated for 7 cycles. After the experiment, set the four reactors $\mathrm{pH}$ value to 8.5 and repeat the above steps.

\section{Analysis Methods}

The $\mathrm{pH}$ values were determined using a $\mathrm{pH}$ meter (PHS-3C/501, INESA Scientific Instrument Co. Ltd., Shanghai, China) with composite electrodes. The CODCr concentrations were determined using a COD analyzer (DR1010, HACH, Loveland, CO). The produced gas volumes were measured via the drainage method. The mixed liquor suspended solid (MLSS) levels were measured according to the national standard method (National EPA 2002). The dilute sulphuric acid method was used to extract extracellular polymers (Adav and Lee 2008). The phenol-sulfuric acid method was used to quantify the polysaccharides (PS) using glucose as the standard (Dubois et al. 1956). The protein (PN) contents were determined with a modified Lowry method using bovine serum albumin as the standard (Frolund et al. 1996). The VFAs (volatile fatty acids) were determined using a GC2014C gas chromatograph (Shimadzu, Kyoto, Japan) with an ID detector and a DBFFAP capillary column with a specification of $30 \mathrm{~mm}$ ID $\times 0.32 \mathrm{~mm}$ ID $\times 0.25 \mu \mathrm{m}$. The capillary column flow rate was adjusted to $75 \mathrm{~mL} / \mathrm{min}$, with $2 \mu \mathrm{m}$ for each injection, and a shunt injection at a ratio of 5 to 1 . In addition, the temperature of the inlet, detector, and cylinder were set as $220{ }^{\circ} \mathrm{C}, 230{ }^{\circ} \mathrm{C}$, and $100{ }^{\circ} \mathrm{C}$, respectively. The temperature of the $6{ }^{\circ} \mathrm{C} / \mathrm{min}$ program rose to a temperature of $130{ }^{\circ} \mathrm{C}$ and remained at this temperature for 1 min, then rose to a temperature of $190^{\circ} \mathrm{C}$ at a rate of $10^{\circ} \mathrm{C} / \mathrm{min}$ and stayed constant for 2 $\min$.

\section{RESULTS AND DISCUSSION}

\section{The Effect of pH Shock on Anaerobic System Performance}

When the system was operated under optimal conditions of $\mathrm{pH} 6.7$ to 7.5 and temperature $37^{\circ} \mathrm{C}$, the average gas production of the blank, $\mathrm{GO}, \mathrm{Fe}^{0}$, and $\mathrm{Fe}^{0} / \mathrm{GO}$ reactors was 488, 496, 505, and $511 \mathrm{~mL}$, respectively. Then the four groups of reactors were subjected to a $\mathrm{pH} 5.5$ and 8.5 shock treatment. The resulting gas production values of the reactors are shown in Fig. 2. When the influent was in the shock stage of $\mathrm{pH} 5.5$, the gas production of blank group, $\mathrm{GO}$ group, $\mathrm{Fe}^{0}$ group, and $\mathrm{Fe}^{0} / \mathrm{GO}$ group was 260, 280, 320, and $345 \mathrm{~mL}$, respectively. Gas production increased to $375,395,410$, and $450 \mathrm{~mL}$, respectively, when influent $\mathrm{pH}$ was restored to the optimal range of 6.7 to 7.5 . In contrast, the gas production of the four groups reached 250, 275, 290, and $310 \mathrm{~mL}$, respectively, when the influent was in the shock stage of $\mathrm{pH} 8.5$, and the gas production increased to 360 , 390,400 , and $415 \mathrm{~mL}$ when the $\mathrm{pH}$ returned to the optimal range of 6.7 to 7.5 . By analyzing the data shown in Figs. 2 and 3, it was found that the gas production of the $\mathrm{Fe}^{0}$ and $\mathrm{Fe}^{0} / \mathrm{GO}$ reactors was higher than the gas production of the blank group and GO group. As shown in Figs. 2A and 2B, the gas production treatment effect of the $\mathrm{Fe}^{0}$ and $\mathrm{Fe}^{0} / \mathrm{GO}$ reactors under a $\mathrm{pH}$ shock of 5.5 was better than the gas production under a $\mathrm{pH}$ shock of 8.5 . In addition, the recovery of system gas production after $\mathrm{pH} 5.5$ shock is better than that after $\mathrm{pH} 8.5$ shock. By analyzing the results, it was found that when the $\mathrm{pH}$ shock was 5.5 , the 
effluent $\mathrm{pH}$ of the system was stable, between 6.7 and 7.5 (as shown in Fig. 3A). At this time, the methanogens were at an optimal $\mathrm{pH}$ range and had high activity. By contrast, at a $\mathrm{pH}$ shock of 8.5 , the water $\mathrm{pH}$ was greater than 7.5 (as shown in Fig. 3B), and the methanogen activity for the four groups of reactors was suppressed. It was found that the addition of $\mathrm{Fe}^{0}$ increased the concentration of $\mathrm{Fe}^{2+}$ and $\mathrm{Fe}^{3+}$ in the system, thus increasing the methane production rate $\left(\mathrm{Hu}\right.$ et al. 2015). Moreover, $\mathrm{Fe}^{3+}$ has also been shown to accelerate the electron transfer rate by promoting the direct interspecific electron transfer of anaerobic microorganisms in a fermentation system, thus promoting methane production (Li et al. 2015). However, this may also be due to the reaction of $\mathrm{Fe}^{0}$ with water to produce $\mathrm{H}_{2}$ and $\mathrm{OH}^{-}$, as shown in Eq. 1,

$$
\mathrm{Fe}^{0}+2 \mathrm{H}_{2} \mathrm{O} \rightarrow \mathrm{Fe}^{2+}+\mathrm{H}_{2}+2 \mathrm{OH}^{-}
$$

This process increased the $\mathrm{pH}$ of the $\mathrm{Fe}^{0}$ and $\mathrm{Fe}^{0} / \mathrm{GO}$ anaerobic digestion systems, maintaining the $\mathrm{pH}$ of the system within a range of 6.7 to 7.5 for the methanogens, and thus promoting an increase in gas production in the anaerobic system (Ma et al. 2018). This explains the high gas production of the $\mathrm{Fe}^{0}$ and $\mathrm{Fe}^{0} / \mathrm{GO}$ reactors, and why the gas production under a $\mathrm{pH}$ shock of 5.5 was better than a $\mathrm{pH}$ shock of 8.5.
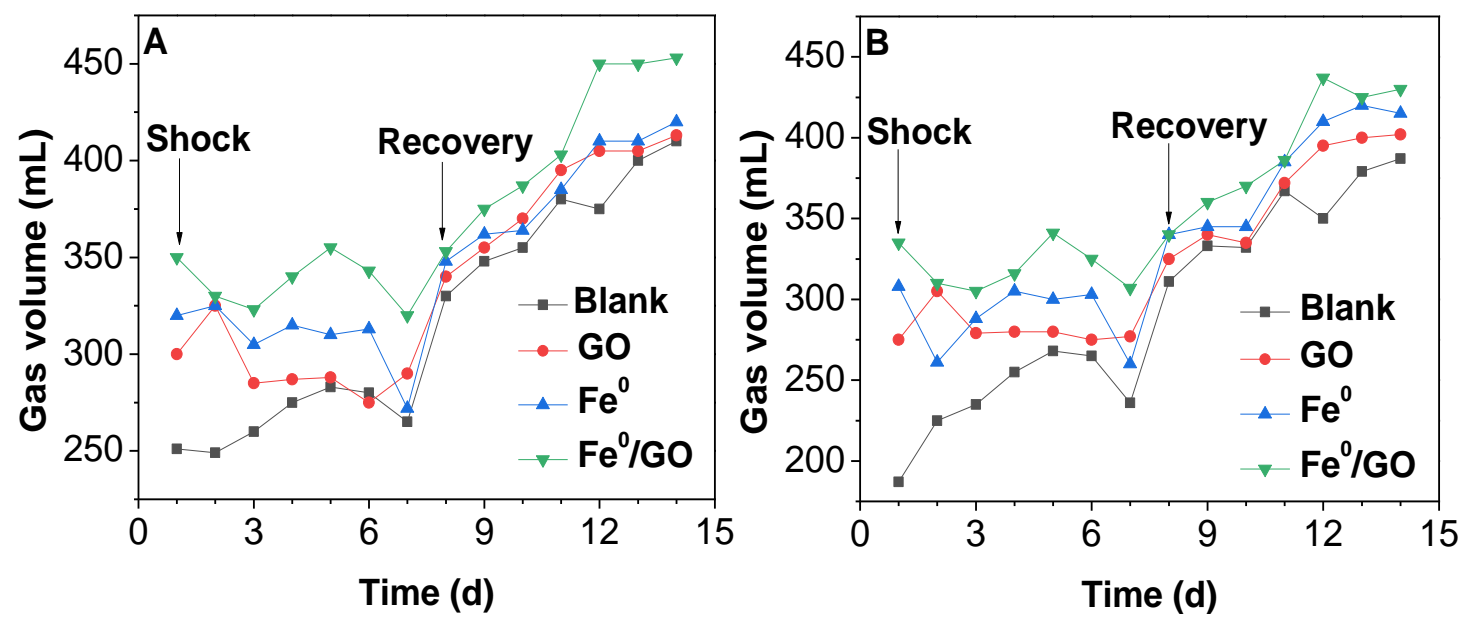

Fig. 2. Effect of the $\mathrm{pH}$ shock on the gas volume: $\mathrm{A}) \mathrm{pH}=5.5$; and $\mathrm{B}) \mathrm{pH}=8.5$
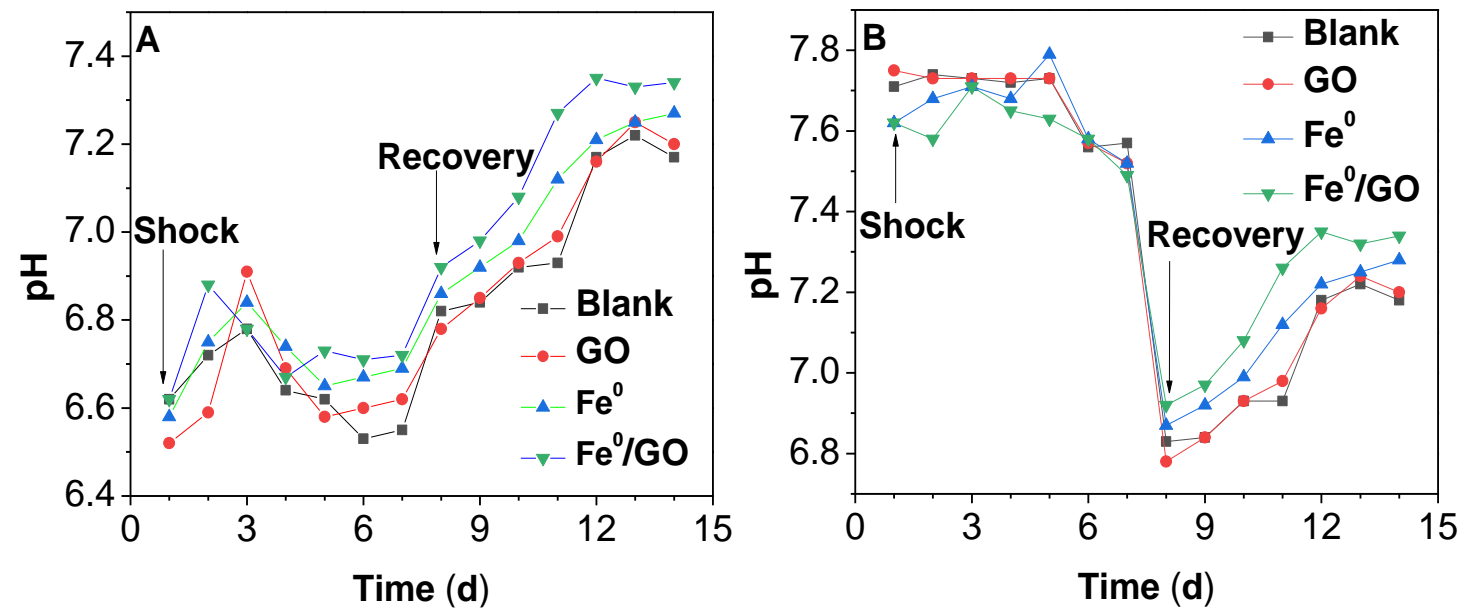

Fig. 3. Effect of the $\mathrm{pH}$ shock on the $\mathrm{pH}$ of the effluent: $\mathrm{A}) \mathrm{pH}=5.5$; and $\mathrm{B}$ ) $\mathrm{pH}=8.5$ 
When the system was operated under optimal conditions of $\mathrm{pH} 6.7$ to 7.5 and temperature $37{ }^{\circ} \mathrm{C}$, the $\mathrm{COD}_{\mathrm{Cr}}$ removal rates of the blank, $\mathrm{GO}, \mathrm{Fe}^{0}$, and $\mathrm{Fe}^{0} / \mathrm{GO}$ reactors were $82.7 \%, 85.8 \%, 88.9 \%$, and $91.8 \%$, respectively, which basically remained above $80 \%$. The $\mathrm{COD}_{\mathrm{Cr}}$ removal rate in the $\mathrm{Fe}^{0} / \mathrm{GO}$ group was the highest, followed by the $\mathrm{Fe}^{0}$ group and the blank group. The $\mathrm{COD}_{\mathrm{Cr}}$ removal rates of the four reactors after they experienced $\mathrm{pH} 5.5$ and 8.5 shock are shown in Fig 4. The CODCr removal rates of the blank, $\mathrm{GO}, \mathrm{Fe}^{0}$, and $\mathrm{Fe}^{0} / \mathrm{GO}$ groups were stable at $28.8 \%, 32.5 \%, 48.3 \%$, and $49.6 \%$, respectively, under a $\mathrm{pH}$ shock of 5.5. After the $\mathrm{pH}$ of the reactor returned to the optimal range of 6.7 to 7.5 , the $\mathrm{COD}_{\mathrm{Cr}}$ removal rates were $71.2 \%, 75.8 \%, 79.9 \%$, and $82.5 \%$, respectively. When the influent $\mathrm{pH}$ was 8.5 , the $\mathrm{CODCr}_{\mathrm{Cr}}$ removal rate was stable at $35.2 \%$, $37.5 \%, 40.5 \%$, and $42.3 \%$, respectively. The $\mathrm{COD}_{\mathrm{Cr}}$ removal rates of the reactor were $69.8 \%, 74.6 \%, 77.8 \%$, and $80.5 \%$, respectively, after the reactor returned to the optimal range of 6.7 to 7.5. The $\mathrm{CODCr}_{\mathrm{Cr}}$ removal rate of the $\mathrm{Fe}^{0}$ and $\mathrm{Fe}^{0} / \mathrm{GO}$ reactors under a $\mathrm{pH}$ shock of 5.5 was higher than the $\mathrm{COD}_{\mathrm{Cr}}$ removal rate under a $\mathrm{pH}$ shock of 8.5 , and the recovery of the $\mathrm{COD}_{\mathrm{Cr}}$ removal rate after an acid shock was also better than the recovery after an alkaline shock, which was consistent with the results of the gas production of the system.
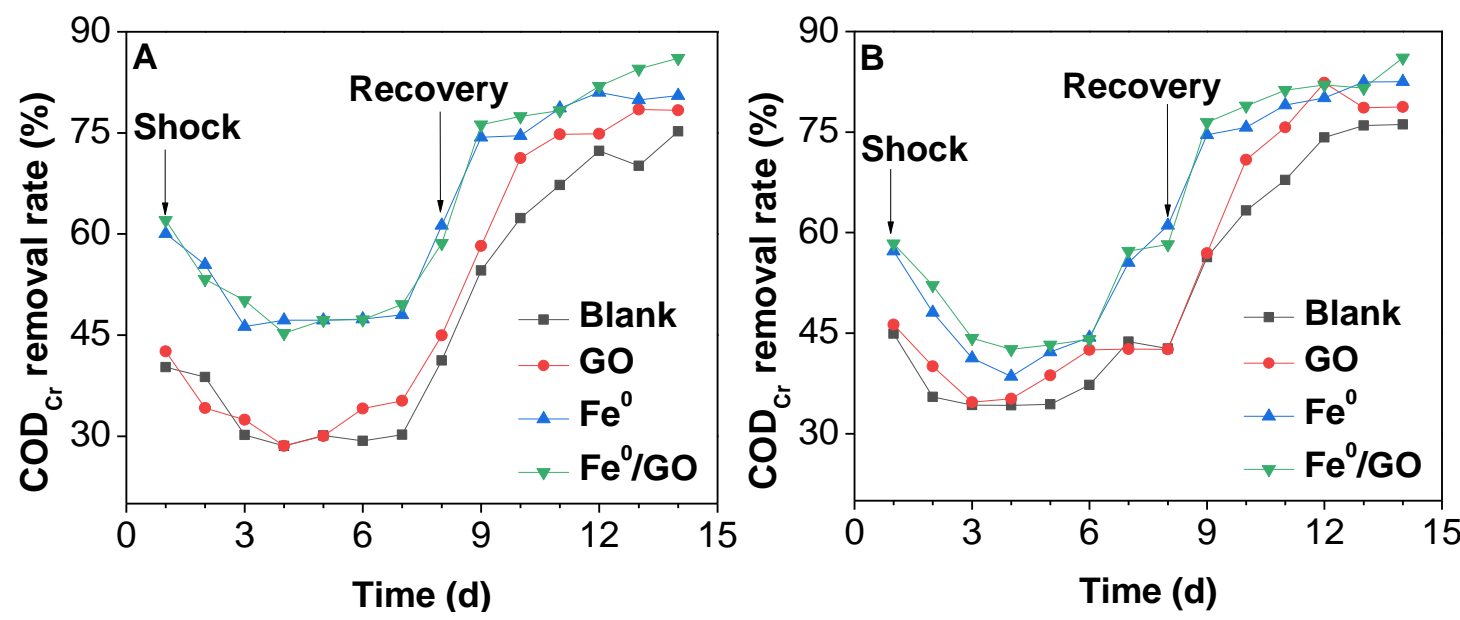

Fig. 4. Effect of the $\mathrm{pH}$ shock on the $\mathrm{COD}_{\mathrm{cr}}$ removal rate: $\left.\mathrm{A}\right) \mathrm{pH}=5.5$; and $\left.\mathrm{B}\right) \mathrm{pH}=8.5$

When the four groups of reactors were subjected to $\mathrm{pH} 5.5$ and 8.5 shock, the removal rate of the $\mathrm{COD}_{\mathrm{Cr}}$ and gas production in the $\mathrm{Fe}^{0} / \mathrm{GO}$ group were the highest, and the gas production and $\mathrm{COD}_{\mathrm{Cr}}$ removal rate in the $\mathrm{Fe}^{0}$ group were higher than those in the $\mathrm{GO}$ group, which indicated that the promotion effect of $\mathrm{Fe}^{0}$ on the CODCr removal rate and the gas production was better than the promotion effect of $\mathrm{Fe}^{0}$ in the $\mathrm{GO}$ group. Although GO has a certain adsorption effect on pollutants in wastewater, it also has a certain inhibition effect on the anaerobic methane production process. Studies have shown that in the anaerobic digestion process of sludge, the activity of corresponding enzymes in methanogens (such as coenzyme $\mathrm{F}_{420}$ ) will be reduced as the GO concentration increases, which seriously inhibits methane production (Dong et al. 2018). The addition of $\mathrm{Fe}^{0}$ weakened the GO inhibitory effect on the anaerobic microbes, promoted the sludge anaerobic digestion process, and considerably improved methane production (Wei et al. 2018). However, it also can effectively remove $\mathrm{H}_{2} \mathrm{~S}$, stimulate the anaerobic acidification process and the key enzyme of the methanogenesis process, and effectively reduce the oxidation reduction potential (ORP), so as to provide a comfortable environment for 
anaerobic digestion (Baniamerian et al. 2019). Under $\mathrm{pH}$ shock, the $\mathrm{Fe}^{0} / \mathrm{GO}$ reactor had the best operating effect, which was the result of the combined action of $\mathrm{Fe}^{0}$ and GO. The functional groups on the GO surface provided abundant contact sites for $\mathrm{Fe}^{0}$, which made it more evenly dispersed throughout the system, thus promoting the electron transfer rate of the anaerobic system and making the reaction more sufficient (Ren et al. 2018).

Figure $5 \mathrm{~A}$ and $5 \mathrm{~B}$ show plots based on the kinetics equations of the $\mathrm{COD}_{\mathrm{Cr}}$ degradation of the four reactors under $\mathrm{pH} 5.5$ and $\mathrm{pH} 8.5$ conditions, respectively.
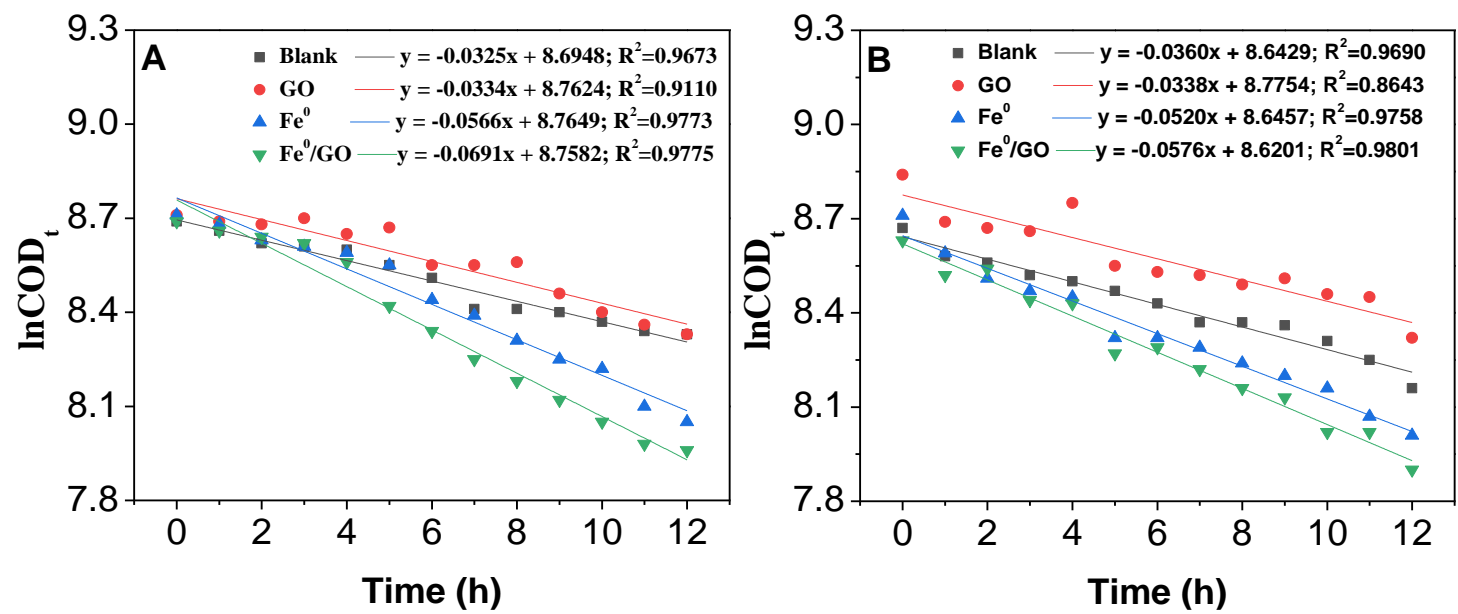

Fig. 5. Fitted curve of the first order kinetics: A) $\mathrm{pH}=5.5$; and $\mathrm{B}$ ) $\mathrm{pH}=8.5$

Table 2. Effect of pH Shock on Degradation Kinetics Equations

\begin{tabular}{|c|c|c|}
\hline \multirow{2}{*}{} & 5.5 & pH Shock Value \\
\cline { 2 - 3 } & $-\frac{d C O D}{d t}=0.0325 C O D$ & 8.5 \\
\hline Blank group & $-\frac{d C O D}{d t}=0.0334 C O D$ & $-\frac{d C O D}{d t}=0.0360 C O D$ \\
\hline $\mathrm{GO}$ group & $-\frac{d C O D}{d t}=0.0566 C O D$ & $-\frac{d C O D}{d t}=0.0338 C O D$ \\
\hline $\mathrm{Fe}^{0}$ group & $-\frac{d C O D}{d t}=0.0691 C O D$ & $-\frac{d C O D}{d t}=0.0520 C O D$ \\
\hline $\mathrm{Fe}^{0} / \mathrm{GO}$ group & $-\frac{d C O D}{d t}=0.0576 C O D$ \\
\hline
\end{tabular}

By comparing the degradation kinetics equations of each system, it was found that the degradation rate constant $(k)$ of the $\mathrm{Fe}^{0} / \mathrm{GO}$ system was the highest for both the $\mathrm{pH} 5.5$ impact and $\mathrm{pH} 8.5 \mathrm{impact}\left(k=0.0691 \mathrm{~h}^{-1}\right.$ at a $\mathrm{pH} 5.5$ impact and $k=0.0576 \mathrm{~h}^{-1}$ at a $\mathrm{pH} 8.5$ impact). In addition, the degradation kinetics of the four groups of reactors was better than the degradation kinetics of the four groups under a $\mathrm{pH} 5.5$ impact. This was consistent with the trend of the $\mathrm{COD}_{\mathrm{Cr}}$ removal rate and the gas production.

The comprehensive analysis of Figs. 2 through 5 showed that when the system was shocked by $\mathrm{pH} 5.5$ and 8.5, the gas production and $\mathrm{COD}_{\mathrm{Cr}}$ removal rate of the four reactor systems decreased, and the effluent $\mathrm{pH}$ fluctuated. The treatment effect of the reactor adding $\mathrm{Fe}^{0}$ / Go was obviously better than the treatment effect of the other three reactors. When the $\mathrm{pH}$ of the reactor was restored to the optimal range of 6.7 to 7.5 , the effluent $\mathrm{pH}$ of the four systems gradually recovered to a stable state, while the gas production and CODCr removal rate of the $\mathrm{Fe}^{0} / \mathrm{GO}$ group increased rapidly and tended to be stable faster. 
This data and the degradation rate constant of the kinetic equation all indicated that the addition of $\mathrm{Fe}^{0}$ and $\mathrm{Go}$ made the system more tolerant to $\mathrm{pH}$ shock, and the $\mathrm{Fe}^{0} / \mathrm{GO}$ reactor had the strongest resistance to $\mathrm{pH}$ shock.

\section{The Effect of pH Shock on the Effluent VFAs}

The influence of $\mathrm{pH}$ shock on VFAs in system effluent is shown in Fig 6.
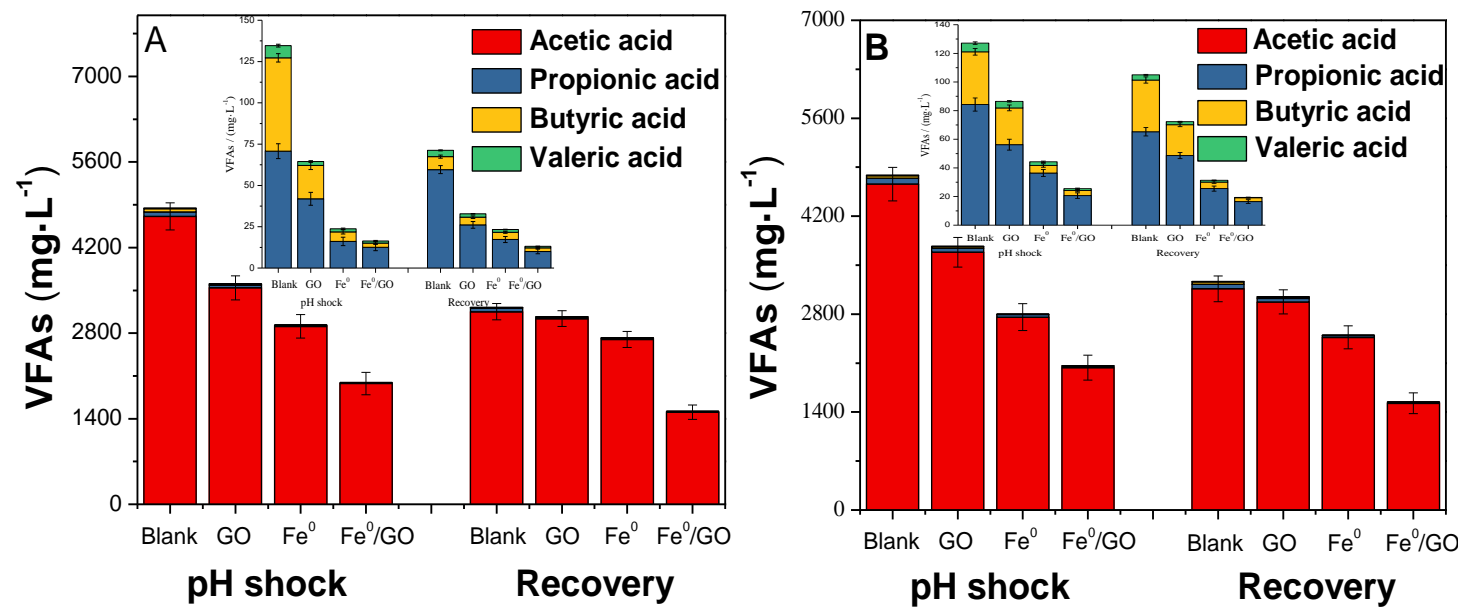

Fig. 6. The effect of $\mathrm{pH}$ shock on VFAs: A) $\mathrm{pH}=5.5$; and $\mathrm{B}) \mathrm{pH}=8.5$

In an anaerobic system, the fermentation type of the microorganisms plays an important role in the process of methane production. Through the determination of the VFAs in the effluent of each system, the influence of $\mathrm{Fe}^{0}$ and $\mathrm{GO}$ on the anaerobic system was studied. There was little difference in the acetic acid content in the same reactor after a pH 5.5 and $\mathrm{pH} 8.5$ shock as well as after recovery. However, the content of the VFAs in each group was considerably different. After the $\mathrm{pH}$ shock, the acetic acid content in the effluent of the blank group, $\mathrm{GO}$ group, $\mathrm{Fe}^{0}$ group, and $\mathrm{Fe}^{0} / \mathrm{GO}$ group were approximately $4700,3500,2850$, and $1900 \mathrm{mg} \cdot \mathrm{L}^{-1}$, respectively. After the $\mathrm{pH}$ returned to the optimal range of 6.7 to 7.5 , the acetic acid content in the effluent of the blank group, GO group, $\mathrm{Fe}^{0}$ group and $\mathrm{Fe}^{0} / \mathrm{GO}$ group were $3000,2900,2600$, and $1400 \mathrm{mg} \cdot \mathrm{L}^{-1}$, respectively. The acetic acid content in each system always maintained at a high level (greater than 90\%), which indicated that the acetic acid type climax community was always the dominant acid production and fermentation climax community in the anaerobic system. By comparing the propionic acid and butyric acid contained in the systems, it was found that under $\mathrm{pH}$ shock conditions, the propionic acid content in the $\mathrm{Fe}^{0}$ and $\mathrm{Fe}^{0} / \mathrm{GO}$ groups was considerably lower than the propionic acid content in the blank and GO groups, which may be because the addition of $\mathrm{Fe}^{0}$ promoted the transformation of propionic acid. Meng et al. (2013) found in their study that adding iron powder to an anaerobic digestion system can reduce the free energy required for propionic acid decomposition, increase the activity of enzymes related to acetic acid production, and improve the conversion efficiency of propionic acid to acetic acid. At the same time, the addition of $\mathrm{Fe}^{0}$ increased the number and diversity of the microbial community, especially the bacteria responsible for propionic acid transformation. Ye et al. (2021) found that iron was an important component of some coenzymes in anaerobic bacteria.

During the stage of hydrolytic acidification, the activities of dehydrogenase, acetic kinase, phosphotransacetylase, and butyrate kinase were increased by $47.8 \%$ to $88.1 \%$ with 
the addition of $\mathrm{Fe}^{0}$, which was conducive to the conversion of propionate and butyrate to acetate. Therefore, a large amount of acetic acid produced via hydrolytic acidification can be rapidly utilized by methanogens. It can be seen from Fig. 6 that the $\mathrm{Fe}^{0}$ group was better than the GO group in promoting acetic acid decomposition, and the effluent VFAs content of the $\mathrm{Fe}^{0} / \mathrm{GO}$ group was much lower than the effluent VFAs content of the other three groups after $\mathrm{pH}$ shock and after recovery. This was primarily due to the addition of $\mathrm{Fe}^{0}$ and GO, which promoted the synthesis of key enzymes in the process of methane production as well as improved enzyme activity, enabled the anaerobic system to maintain enzyme function under the impact of $\mathrm{pH}$, sped up the conversion of VFAs to methane, and reduced the accumulation of VFAs in the system. At the same time, $\mathrm{Fe}^{0}$ promoted the transformation of methanogenic dominant bacteria from Methanothrix to Methanosarcina thermophila (its acetic acid utilization rate was 3 to 5 times higher than Methanothrix) in the anaerobic reactor, thus accelerating the utilization of acetic acid (Wei et al. 2018). These two effects accelerated the conversion of VFAs to methane in the anaerobic system, while the addition of $\mathrm{GO}$ made the $\mathrm{Fe}^{0}$ dispersion more uniform, which further improved the treatment effect of the $\mathrm{Fe}^{0} / \mathrm{GO}$ system on high concentration organic wastewater. Combined with various effluent indicators, the changes in the VFAs content in each system further verified that the system showed a stronger impact tolerance to $\mathrm{pH}$ when $\mathrm{Fe}^{0}$ and GO are added.

\section{Influence of pH Shock on System Mixed Liquor Suspended Solid (MLSS)}

The impact of pH 5.5 and 8.5 shock on the MLSS of the system is shown in Fig 7. The charge on the surface of the microorganisms changed as the four reactors were subjected to $\mathrm{pH}$ shock, which affected the activity of the enzymes of the microorganisms, which in turn affected the growth of the organisms. After a $\mathrm{pH}$ shock of 5.5, the blank, GO, $\mathrm{Fe}^{0}$, and $\mathrm{Fe}^{0} / \mathrm{GO}$ systems was reduced to $7.40,7.41,7.80$, and $7.85 \mathrm{~g} \cdot \mathrm{L}^{-1}$; after a $\mathrm{pH}$ shock of 8.5 , the MLSS was reduced to $7.30,7.33,7.70$, and $7.75 \mathrm{~g} \cdot \mathrm{L}^{-1}$. The microbial activity gradually increased while the $\mathrm{pH}$ of the inlet water returned to the optimal range of 6.7 to 7.5. At the same time, MLSS concentration in $\mathrm{Fe}^{0}$ and $\mathrm{Fe}^{0} / \mathrm{GO}$ groups increased to slightly higher than that in blank group and GO group, the MLSS in the $\mathrm{Fe}^{0} / \mathrm{GO}$ group changed the most. After recovery, the MLSS increased by $0.38 \mathrm{~g} \cdot \mathrm{L}^{-1}(\mathrm{pH} 5.5)$ and $0.29 \mathrm{~g} \cdot \mathrm{L}^{-1}(\mathrm{pH} 8.5)$ compared with the shock. These results were consistent with the $\mathrm{CODCr}_{\mathrm{Cr}}$ removal rate and gas production results. The MLSS value of the $\mathrm{Fe}^{0} / \mathrm{GO}$ group in the $\mathrm{pH}$ shock phase and the recovery phase was the highest among the four reactors, which indicated that the growth and reproduction of the microorganisms in this reactor was the best, which was consistent with the $\mathrm{COD}_{\mathrm{Cr}}$ removal rate and production of the reactor with $\mathrm{Fe}^{0} / \mathrm{GO}$. This is because iron plays an important role in the metabolic mechanism of a variety of anaerobic microorganisms, which can accelerate the growth and reproduction of anaerobic microorganisms while promoting the conversion of complex organic matter to biogas, and thus shows the growth of MLSS (Yekta et al. 2014). However, under the action of $\mathrm{Fe}^{0}$, a large number of anaerobic microorganisms took advantage of the large specific surface area of GO to enrich and grow, so that anaerobic activated sludge can maintain a dense structure under $\mathrm{pH}$ impact and improve the sludge floc and microbial population structure to a certain extent (Liang et al. 2017). These results indicated that the $\mathrm{Fe}^{0} / \mathrm{GO}$ reactor had strong impact resistance. Under the impact of $\mathrm{pH}$, the degree of damage to the system and the degree of sludge loss were lower than other reactors and the MLSS in the system was higher. In addition, the pollutant degradation effect was better. Therefore, adding $\mathrm{Fe}^{0} / \mathrm{GO}$ to the reactor can enhance the anti-pH shock ability of anaerobic microorganisms. 

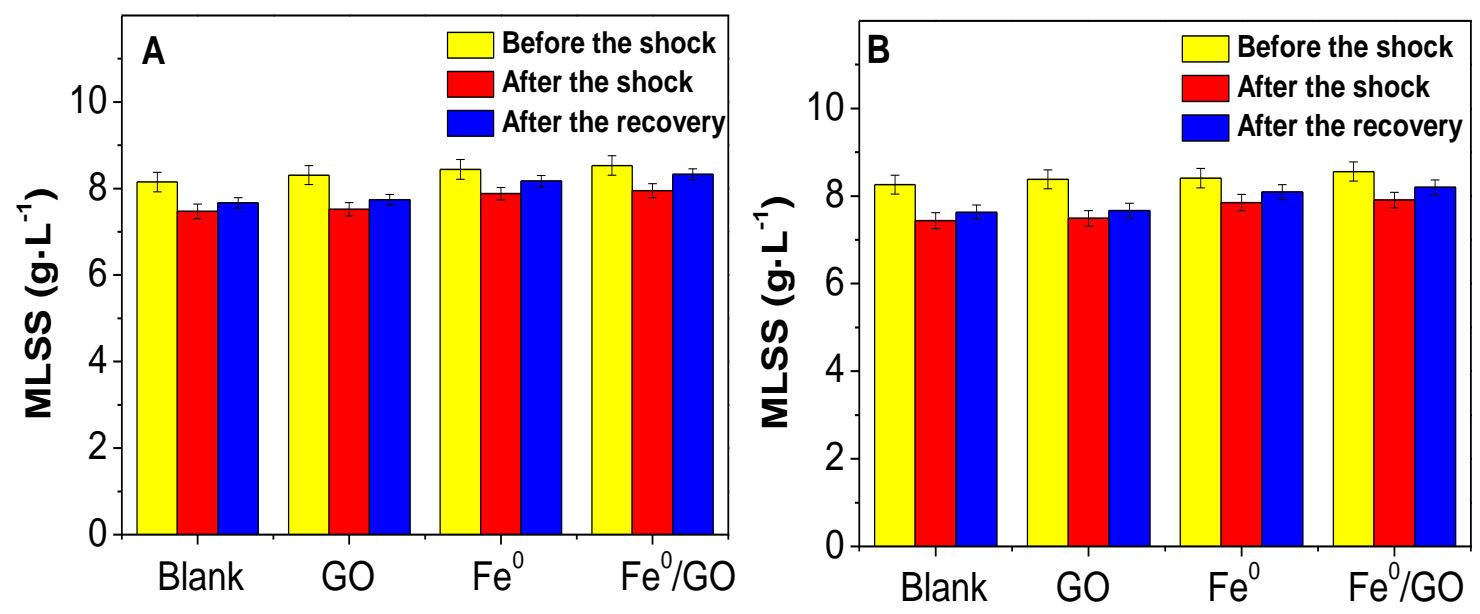

Fig. 7. The effect of $\mathrm{pH}$ shock on the MLSS: A) $\mathrm{pH}=5.5$; and $B) \mathrm{pH}=8.5$

\section{The Effect of pH Shock on the Extracellular Polymers}

The effect of $\mathrm{pH} 5.5$ and 8.5 shock on the extracellular polymers is shown in Fig. 8. Extracellular polymeric substances (EPS) contain three-dimensional, gel-like, highly hydrated, charged characteristics. As the skeleton of microbial aggregates, EPS can considerably promote the aggregation of microorganisms and maintain the stability of microbial aggregates (Zhang et al. 2019). Extracellular polymeric substances consist of proteins (PN), polysaccharides (PS), nucleic acids, and humic acid (HA) (Desmond et al. 2018). The flocculation performance of sludge usually is reflected by the content and ratio of PN and PS. Proteins can maintain the integrity and stability of the sludge through the three-dimensional structure formed by bridges with cations because the binding capacity of PN and cations is greater than the binding capacity of PS. Therefore, the higher the PN content, the stronger the sludge flocculation ability, which is beneficial to the separation of sludge and water (Campo et al. 2018). As shown in Fig 8, at the system was subjected to $\mathrm{pH} 5.5$ and 8.5 shock and recovery to the optimal range of 6.7 to 7.5 , the PN and PS contents in the sludge extracellular polymer of each reactor under different $\mathrm{pH}$ shock conditions were not much different. However, the PN/PS values of the blank, GO, $\mathrm{Fe}^{0}$, and $\mathrm{Fe}^{0} / \mathrm{GO}$ groups were quite different during the pH5.5 and 8.5 shock and after recovery. Whether during the $\mathrm{pH} 5.5$ and 8.5 shock or after the system recovery, the PN/PS value of the $\mathrm{Fe}^{0} / \mathrm{GO}$ system was considerably higher than the other three systems, which indicated the addition of $\mathrm{Fe}^{0}$ promoted the growth of PN in the EPS, thereby improving the flocculation performance of sludge. The $\mathrm{Fe}^{0} / \mathrm{GO}$ group took full advantage of $\mathrm{Fe}^{0}$ and $\mathrm{GO}$, making the PN/PS value considerably higher than the other three groups. Zhang et al. (2018) found that the addition of $\mathrm{Fe}^{0}$ increased the concentration of $\mathrm{Fe}^{3+}$ in the system. $\mathrm{Fe}^{3+}$ acts as a chelating agent to promote the production of EPS and contributes to an increase in the PN content in EPS. At the same time, $\mathrm{Fe}^{3+}$ also promotes PS secretions from microorganisms. Therefore, the addition of $\mathrm{Fe}^{0}$ and $\mathrm{GO}$ is beneficial for promoting the increase of the PN and PS content of the sludge, enhancing the anti-pH shock ability of the system, and reducing the negative impact caused by the $\mathrm{pH}$ shock. Thus, the integrity and stability of the sludge are maintained, the efficiency of sludge-water separation increases, and the wastewater treatment effect is improved. 

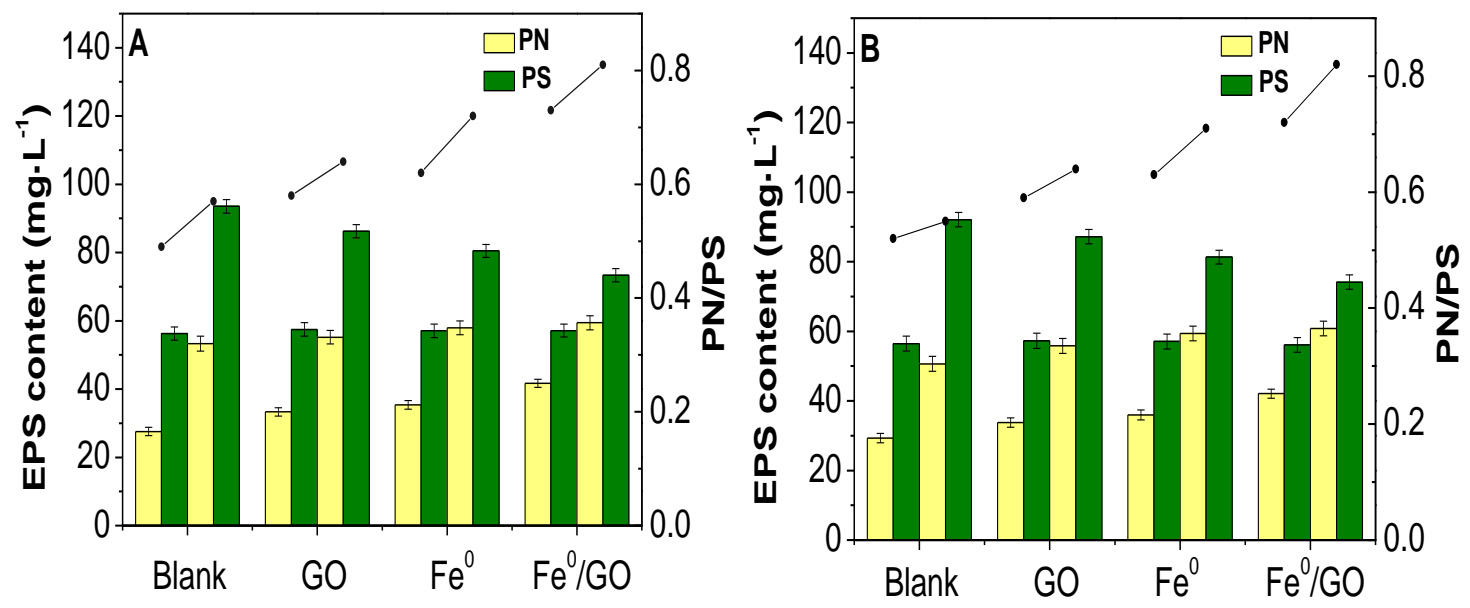

Fig. 8. The effect of $\mathrm{pH}$ shock on the EPS: $\mathrm{A}$ ) $\mathrm{pH}=5.5$; and $\mathrm{B}$ ) $\mathrm{pH}=8.5$ (Note: the bar chart shows the content of the EPS, while the line chart shows the PN/PS; S represents the PN, PS, and PN/PS content after the $\mathrm{pH}$ shock; and $\mathrm{R}$ represents the content of the PN, PS, and PN/PS content after the $\mathrm{pH}$ recovery.)

\section{CONCLUSIONS}

1. In the impact experiment, the reactor with $\mathrm{Fe}^{0}$ was less affected by $\mathrm{pH}$ shock. Compared with the reactor without $\mathrm{Fe}^{0}$, the reactor with $\mathrm{Fe}^{0}$ had higher gas production, higher $\mathrm{COD}_{\mathrm{Cr}}$ removal rate and lower effluent VFAs content. Nevertheless, the promotion effect of $\mathrm{GO}$ was not evident in the $\mathrm{pH}$ impact test.

2. In the recovery experiment, the gas production and $\mathrm{COD}_{\mathrm{Cr}}$ removal rate of the $\mathrm{Fe}^{0} / \mathrm{GO}$ reactor were higher than the gas production and $\mathrm{CODCr}_{\mathrm{C}}$ removal rate of the other three reactors; the effluent VFAs content was the lowest, and the recovery time was shorter.

3. Through the analysis of the physical and chemical characteristics of anaerobic activated sludge, it was found that the increase rate of MLSS and PN/PS value in $\mathrm{Fe}^{0} / \mathrm{GO}$ group were better than the other three groups in both $\mathrm{pH}$ shock stage and recovery stage, which indicated that after a $\mathrm{pH}$ impact, the synergy of $\mathrm{Fe}^{0}$ and $\mathrm{GO}$ ensured the anaerobic system had relatively good flocculation performance and greater recoverability of the system.

\section{ACKNOWLEDGMENTS}

The authors are grateful for the Research Fund Program of Guangdong Provincial Key Lab of Green Chemical Product Technology (Grant No. GC202112).

\section{Competing Interests}

The authors declare that they have no conflict of interest.

\section{Author Contribution Statement}

Yecheng Lin and Huixia Lan conceived and designed the research. Yecheng Lin and Xiangzhi Wang conducted the experiments. Da Yang contributed new reagents or 
analytical tools. Yecheng Lin and Longyu Wang analyzed the data. Yecheng Lin wrote the manuscript. All authors read and approved the manuscript.

\section{Consent to Participate}

All authors consented to participate in the manuscript.

\section{Consent to Publish}

All authors consented to publish this manuscript.

\section{REFERENCES CITED}

Adav, S. S., and Lee, D.-J (2008). "Extraction of extracellular polymeric substances from aerobic granule with compact interior structure," Journal of Hazardous Materials 154(1-3), 1120-1126. DOI: 10.1016/j.jhazmat.2007.11.058

Appels, L., Baeyens, J., Degreve, J., and Dewil, R. (2008). "Principles and potential of the anaerobic digestion of waste-activated sludge," Progress in Energy and Combustion Science 34(6), 755-781. DOI: 10.1016/j.pecs.2008.06.002

Baniamerian, H., Isfahani, P. G., Tsapekos, P., Alvarado-Morales, M., Vossoughi, M., and Angelidaki, I. (2019). "Application of nano-structured materials in anaerobic digestion: current status and perspectives," Chemosphere 229, 188-199. DOI: 10.1016/j.chemosphere.2019.04.193

Braguglia, C. M., Gallipoli, A., Gianico, A., and Pagliaccia, P. (2017). "Anaerobic bioconversion of food waste into energy: A critical review," Bioresource Technology 248, 37-56. DOI: 10.1016/j.biortech.2017.06.145

Campo, R., Corsino, S. F., Torregrossa, M., and Bella, G. D. (2018). "The role of extracellular polymeric substances on aerobic granulation with stepwise increase of salinity," Separation and Purification Technology 195, 12-20. DOI: 10.1016/j.seppur.2017.11.074

Desmond, P., Best, J. P., Morgenroth, E., and Derlon, N. (2018). "Linking composition of extracellular polymeric substances (EPS) to the physical structure and hydraulic resistance of membrane biofilms," Water Research 132, 211-221. DOI: 10.1016/j.watres.2017.12.058

Dong, B., Xia, Z., Sun, J., Dai, X., Chen, X., and Ni, B.-J. (2018). “The inhibitory impacts of nano-graphene oxide on methane production from waste activated sludge in anaerobic digestion," Science of The Total Environment 646, 1376-1384. DOI: 10.1016/j.scitotenv.2018.07.424

Dubois, M., Gilles, K. A., Hamilton, J. K., Rebers, P. A., and Smith, F. (1956). "Colorimetric method for determination of sugars and related substances," Analytical Chemistry 28(3), 350-356. DOI: 10.1021/ac60111a017

Fan, L., Guo, K., Duan, H., Shao, L., and He, P. (2018). "Exploit carbon materials to accelerate initiation and enhance process stability of co anaerobic open-culture fermentation," ACS Sustainable Chemistry \& Engineering 6(2), 2787-2796. DOI: 10.1021/acssuschemeng.7b04589

Frølund, B., Palmgren, R., Keiding, K., and Nielsen, P. H. (1996). "Extraction of extracellular polymers from activated sludge using a cation exchange resin," Water Research 30(8), 1749-1758. DOI: 10.1016/0043-1354(95)00323-1

$\mathrm{Hu}$, Y., Hao, X., Zhao, D., and Fu, K. (2015). "Enhancing the $\mathrm{CH}_{4}$ yield of anaerobic 
digestion via endogenous $\mathrm{CO}_{2}$ fixation by exogenous $\mathrm{H}_{2}$," Chemosphere 140, 34-39. DOI: 10.1016/j.chemosphere.2014.10.022

Ji, C., Yao, B., Li, C., and Shi, G. (2013). “An improved Hummer's method for ecofriendly synthesis of graphene oxide," Carbon 64(11), 225-229. DOI:

10.1016/j.carbon.2013.07.055

Jia, H., Yang, G., Ngo, H.-H., Guo, W., Zhang, H., Gao, F., and Wang, J. (2017). "Enhancing simultaneous response and amplification of biosensor in microbial fuel cell-based upflow anaerobic sludge bed reactor supplemented with zero-valent iron," Chemical Engineering Journal 327, 1117-1127. DOI: 10.1016/j.cej.2017.06.181

Kong, X., Wei, Y., Xu, S., Liu, J., Li, H., Liu, Y., and Yu, S. (2016). “Inhibiting excessive acidification using zero-valent iron in anaerobic digestion of food waste at high organic load rates," Bioresource Technology 211, 65-71. DOI: 10.1016/j.biortech.2016.03.078

Konios, D., Stylianakis, M. M., Stratakis, E., and Kymakis, E. (2014). "Dispersion behaviour of graphene oxide and reduced graphene oxide," Journal of Colloid and Interface Science 430, 108-112. DOI: 10.1016/j.jcis.2014.05.033

Li, H., Chang, J., Liu, P., Fu, L., Ding, D., and Lu, Y. (2015). "Direct interspecies electron transfer accelerates syntrophic oxidation of butyrate in paddy soil enrichments," Environmental Microbiology 17(5), 1533-1547. DOI: 10.1111/14622920.12576

Liang, X.-Y., Gao, S.-Q., and Ni, S.-Q. (2017). "Effects of magnetic nanoparticles on aerobic granulation process," Bioresource Technology 227, 44-49. DOI: 10.1016/j.biortech.2016.12.038

Liu, Y., Zhang, Y., Quan, X., Yang, L., Zhao, Z., Meng, X., and Chen, S. (2012). "Optimization of anaerobic acidogenesis by adding $\mathrm{Fe}^{0}$ powder to enhance anaerobic wastewater treatment," Chemical Engineering Journal 192, 179-185. DOI: 10.1016/j.cej.2012.03.044

Lu, Y., Zhang, Q., Wang, X., Zhou, X., and Zhu, J. (2020). "Effect of pH on volatile fatty acid production from anaerobic digestion of potato peel waste," Bioresource Technology 316(3), 1-8. DOI: 10.1016/j.biortech.2020.123851

Ma, L., Zhou, L., Mbadinga, S. M., Gu, J.-D., and Mu, B.-Z. (2018). "Accelerated $\mathrm{CO}_{2}$ reduction to methane for energy by zero valent iron in oil reservoir production waters," Energy 147, 663-671. DOI: 10.1016/j.energy.2018.01.087

Meng, X., Zhang, Y., Li, Q., and Quan, X. (2013). "Adding $\mathrm{Fe}^{0}$ powder to enhance the anaerobic conversion of propionate to acetate," Biochemical Engineering Journal 73, 80-85. DOI: 10.1016/j.bej.2013.02.004

National EPA (2002) Monitoring Methods of Water and Wastewater, Environmental Scientifc Publishing Company, Peking, China.

Perreault, F., Andreia, F., and Elimelech, M. (2015). "Environmental applications of graphene-based nanomaterials," Chemical Society Reviews 44(16), 5861-5896. DOI: 10.1039/C5CS00021A

Poh, P. E., and Chong, M. F. (2009). "Development of anaerobic digestion methods for palm oil mill effluent (POME) treatment," Bioresource Technology 99(1), 1-9. DOI: 10.1016/j.biortech.2008.06.022

Ren, L., Dong, J., Chi, Z., and Huang, H. (2018). "Reduced graphene oxide-nano zero value iron (rGO-nZVI) micro-electrolysis accelerating $\mathrm{Cr}(\mathrm{VI})$ removal in aquifer," Journal of Environmental Sciences 73(11), 96-106. DOI: 10.1016/j.jes.2018.01.018

Smith, A. T., Lachance, A. M., Zeng, S., Liu, B., and Sun, L. (2019). "Synthesis, 
properties, and applications of graphene oxide/reduced graphene oxide and their nanocomposites," Nano Materials Science 1(1), 31-47. DOI:

10.1016/j.nanoms.2019.02.004

Stefaniuk, M., Oleszczuk, P., and Różyło, K. (2016). "Review on nano zerovalent iron (nZVI): from synthesis to environmental applications," Chemical Engineering Journal 287, 618-632. DOI: 10.1016/j.cej.2015.11.046

Teng, W., Fan, J., Wang, W., Bai, N., Liu, R., Lui, Y., Deng, Y., Kong, B., Yang, J., Zhao, D., et al. (2017). "Nanoscale zero-valent iron in mesoporous carbon (nZVI@C): Stable nanoparticles for metal extraction and catalysis," Journal of Materials Chemistry A 5(9), 4478-4485. DOI: 10.1039/C6TA10007D

Wei, J., Hao, X., van Loosdrecht, M. C. M., and Li, J. (2018). "Feasibility analysis of anaerobic digestion of excess sludge enhanced by iron: A review," Renewable and Sustainable Energy Reviews 89, 16-26. DOI: 10.1016/j.rser.2018.02.042

Wei, W., Cai, Z., Fu, J., Xie, G.-J., Li, A., Zhou, X., Ni, B.-J., Wang, D., and Wang, Q. (2018). "Zero valent iron enhances methane production from primary sludge in anaerobic digestion," Chemical Engineering Journal 351, 1159-1165. DOI: 10.1016/j.cej.2018.06.160

Wu, D., Zheng, S., Ding, A., Sun, G., and Yang, M. (2015). "Performance of a zero valent iron-based anaerobic system in swine wastewater treatment," Journal of Hazardous Materials 286, 1-6. DOI: 10.1016/j.jhazmat.2014.12.029

Ye, W., Lu, J., Ye, J., and Zhou, Y. B. (2021). "The effects and mechanisms of zerovalent iron on anaerobic digestion of solid waste: A mini-review," Journal of Cleaner Production 278, 1-8. DOI: 10.1016/j.jclepro.2020.123567

Yekta, S. S., Lindmark, A., Skyllberg, U., Danielsson, Å., and Svensson, B. H. (2014). "Importance of reduced sulfur for the equilibrium chemistry and kinetics of Fe (II), Co (II) and Ni (II) supplemented to semi-continuous stirred tank biogas reactors fed with stillage," Journal of Hazardous Materials 269, 83-88. DOI: 10.1016/j.jhazmat.2014.01.051

Yi, J. C., Mei, F. C., Law, C. L., and Hassell, D. G. (2009). "A review on anaerobicaerobic treatment of industrial and municipal wastewater," Chemical Engineering Journal 155(12), 1-18. DOI: 10.1016/j.cej.2009.06.041

Zhang, F., Hou, J., Miao, L., Chen, J., Y Xu, You, G., Liu, S., and Ma, J. (2018). "Chlorpyrifos and 3,5,6-trichloro-2-pyridinol degradation in zero valent iron coupled anaerobic system: Performances and mechanisms," Chemical Engineering Journal 353, 254-263. DOI: 10.1016/j.cej.2018.07.136

Zhang, J., Qu, Y., Qi, Q., Zhang, P., Zhang, Y., Tong, Y. W., and He, Y. (2020). “The bio-chemical cycle of iron and the function induced by ZVI addition in anaerobic digestion: A review," Water Research 186, 1-15. DOI: 10.1016/j.watres.2020.116405

Zhang, Z., Cao, R., Jin, L., Zhu, W., Ji, Y., Xu, X., and Zhu, L. (2019). "The regulation of N-acyl-homoserine lactones (AHLs)-based quorum sensing on EPS secretion via ATP synthetic for the stability of aerobic granular sludge," Science of the Total Environment 673, 83-91. DOI: 10.1016/j.scitotenv.2019.04.052

Article submitted: September 2, 2021; Peer review completed: November 14, 2021; Revised version received and accepted: January 10, 2022; Published: January 14, 2022. DOI: 10.15376/biores.17.1.1591-1605 